\title{
Some Critical Themes Regarding the International Migration of Albanians After 1990s
}

\author{
Lekë Sokoli \\ University "Aleksander Moisiu", Durres-Albania \\ Albanian Institute of Sociology (AIS) \\ E-mail: Isokoli@instituti-sociologjise.al; Isokoli@hotmail.com;
}

\section{Doi:10.5901/mjss.2014.v5n1p69}

\begin{abstract}
The phenomenon of migration has been at the core of economic and social changes of Albania during last two decades. No other European Country has been affected to such extent by migration in such a short period of time. That's why Albania as considered a kind of Laboratory for studying the migratory phenomenon in new Europe and global world. Trying to understand the international migration of Albanians and its meaning, the author treats some Critical Themes of migration, speaking generally. First one is concerned with the size of Albanian migration: from one third (people born in Albania living abroad) to half (Albanian that have experienced migration, during the same period of time). Another Critical Theme is concerned with migrants, as contributors on Albanian economy. The third Critical Theme is concerning with the conclusion that the international mobility of people is a controversial issue with attitudes ranging from openness and tolerance toward immigrants in good economic times, to reluctance and even xenophobia and resentment, particularly during times of economic slowdowns, unemployment, and financial insecurity. Another Critical Theme is concerning with the asymmetrical development of the world in the time of globalization: the international mobility of goods (commodities) and capital (money) across countries is much freer than the international mobility of people. This can be called the "people's paradox of globalization". Another Critical Theme is concerned with the correlation between migration and development in the net migration countries. Albanian migration has been the key factor of an "extroversion" economy, meaning that internal consumption greatly exceeds the capacity of national production. The author refers, thanks first to migration, the fast globalization of Albanian society and new concepts, such as: transnationalization, "globalizing communitarianism beyond borders", multiculturalism, "Hybridization" of Albania etc.
\end{abstract}

Keywords: migration, social laboratory, critical themes, remittances, transnationalization, globalizing communitarianism, multiculturalism

\section{Albania as Laboratory for Studying the Migratory Phenomenon and Not Only}

Being very representative the migration of Albanians after '1990-s is much studied, not only from Albanian scholars but also from the social scholars of different countries, such as US and UK, Italy and Greece, Switzerland, France, Germany and so many other countries. For example, the last issue of the Journal "Perpjekja" (No. 26-27, January 2011) approaches Albanian migration from diverse perspectives. Just in the preface of this issue is written:

The issue approaches Albanian migration from diverse perspectives, analyzing sociological, cultural and political phenomena relevant to an unprecedented (post-socialist) migration of almost half of the Albanian population between 1990 and 2010. It focuses on the main geographic destinations of the Albanian migration: Italy, Greece, USA, and Western Europe etc.

One of the contributors of this issue is Russell King, from University of Sussex, UK. His article is titled: Albania as a Laboratory for the Study of Migration and Development (King, 2011), where the author explains:

This paper argues that, because of its recent and intense experience of migration set against a background of transition, poverty and underdevelopment, Albania is an excellent laboratory for the study of the dynamic and mutually interdependent relationship between migration and development.

Albanian migration is studied from different approaches. On of them is that of Julie Vullnetari, according to her, the development of Albania itself and its migratory policies, during last two decades of past-communist transition have had this trajectory: "From communist 'gulag' to Balkan 'ghetto' (Vullnetari, 2011). She writes:

The fall of the Berlin Wall which symbolised the collapse of the socialist system in Central and Eastern Europe, was 
viewed with concern by some policy-makers in Western Europe who envisaged potential 'flooding' of their affluent countries with immigrants. Yet, this fear did not materialise and post-communist East-West migration was rather moderate. The exception was Albania, whose emigration displayed features of an exodus - at least in the early 1990s in terms of its ratio to the country's population, its concentration over a short period of time, and the typology of these moves.

From these sources we have (1) "migration of almost half of the Albanian population between 1990 and 2010" and, (2), in all ex-socialist countries of Central and Eastern Europe, the exception was just Albania, whose emigration displayed features of an exodus in terms of its ratio to the country's population, its concentration over a short period of time, and the typology of these moves (Vullnetari, 2011). The exodus of this significant share of the Albanian population since 1990 is considered as one of Europe's newest and most dramatic mass immigrations (King et al. 2006).

But how many Albanians have emigrated, since 1990: one forth (UNDP, 2006), one third (Sokoli \& Hroni, 2006) or half (Perpjekja, 2011)? It's very difficult to give an exact number of the Albanian migrants during the last two decades. That's because the Albanian migration was irregular (illegal) and very chaotic. Anyhow is very easy to joke with statistics or, speaking in the language of Huff [1954, (1985)] it's easy to lie with statistics, such as with the statistics of Albanian migration.

But we have tested some regions of Albania just to explore the relationship between household welfare and irregular migration risk. The results were really surprised. For example, in the families of Roma Community (i.e. the poorest Albanians) of two Albanian districts, named Levan-Fier and Morava-Berat, more than 50 per cent of the people were abroad: 42.4 per cent from Levan-Fier and 60.8 per cent from Morave-Berat (Sokoli \& Hroni, 2006). In these families the remittances are naturally the major factor that distinguishes "poor" or "non-poor" households. Because of migration these families are likely to produce almost nothing. So, sociological surveys prove the greatest dimensions of irregular immigration of Albanians. It's clear that No other Center or East European Country has been so affected by migration, in such a short period of time like Albania. From this point of view, Albanian's experience of irregular migration is "a kind of laboratory for studying the new migratory process" (Rusell King, 2003, De Zwager et al, 2005). Europe).

So, regarding migration Albania is a Sui genres case in the Central and East Europe (ex-communist part of

\section{Understanding the International Migration of Albanians}

In different studies on Albanian migration we can find different explanations, including right and wrong approaches and conclusions, understandings and misunderstandings as well. Why so many Albanians have migrated in this short time, quite different from the other countries?

We must exclude the ethnic diversity factor. It is known that multiethnic states can also be fragile, especially in face of internal upheaval or external threat. Sometimes societies with long history of ethnic tolerance and integration can rapidly become engulfed in ethnic conflicts - hostilities between different ethnic groups or communities. This has recently been the case in the former Yugoslavia, a region renowned for its rich multiethnic heritage. The Balkans has long been the crossroads of Europe. Centuries of migration and the rule of successive empires have produced a diverse, intermixed population. The conflicts in former Yugoslavia have involved attempts at ethnic cleaning, the creation of ethnically homogenous area through the mass expulsion of other ethnic population. Croatia, for example, has become an independent 'mono-ethnic' state; the war which broke out in Bosnia in 1992 involved the ethnic cleaning; the war in Kosovo in 1999 was prompted by charges that Serbian forces were ethnically cleaning the Kosovar Albanian (Muslim) population from the province (in both cases of Bosnia and Kosovo, ethnic conflict becomed international). Western states intervened both diplomatically and military to protect the human rights of ethnic groups. Political repression, ethic cleaning, armed war, genocide - describes the systematic elimination of one ethnic group at the hands of another always have produced international migration. Balkans diary is the most recent example (Giddens, 2004; Rupnik, 2004).

But this is not the case of Albania, which is the most homogenous Balkan country regarding the ethnicity. The case of Albania is different in comparison to Bosnia, Kosovo etc. In Albania there's no arm conflicts, genocide, persecution, ethnic problems, political repression, human rights violation and so on.

The migration of Albanians can be defined as a "peaceful" migration. Social scholars have identified four models of this kind of migration to describe the main global population movement, al least since 1945, which are: the classic model of migration - applies to countries such as Canada, United States or Australia; the colonial model of migration - pursued by countries such as France and United Kingdom, tends to favor immigrants from former colonies over those from other countries; the guest workers model - the immigration in temporary bases, to fulfill demands within the labour market of 
countries such as Germany, Switzerland, Belgium etc.; the irregular migration or illegal migration (Giddens, 2004: 259). Albanian migration has been first and foremost irregular, or illegal migration.

The basic question: what are the forces behind this massive "peaceful" migration of Albanians? It's known that many early theories about migration focused on so-called push factors (referred to dynamics within a country of origin which forced people to emigrate, such as war, famine, and political oppression or population pressures) and pull factors (the features of destination countries which attracted emigrants). More recently 'push and pull factors' have been criticized for offering only a simplistic explanation of a complex process. Instead scholars of migration are looking at migration patterns as 'systems' which are produced through interactions between macro-level (refer to issues such as political situation in the country etc.), and micro-level (refer to the migrant himself) processes.

Economic historians have shown that "the main variation in inequality (differences) in the past 150 years has been among countries rather than within countries. Therefore a main concern of current globalization is the contrasting in income levels, living standards, and economic potential across nations. These international disparities create powerful incentives for international migration. The development of the world is very asymmetric and international movement of people is inevitable.

The asymmetry is even within countries, such as Albania. So, the proportion richest/poorest of Albanian families is 2.1 times higher than the average of other East European (ex-communist) countries (Sokoli, 2011). Here we have another reason for Albanian higher level of migration. The above mentioned reasons of international migration can give satisfied explanation of Albanian exodus of last two decades. So, I'll try to go in another direction. That's because I am convinced that understanding the Albanian international migration means understanding Albania itself and Albanian postcommunist transition.

Albanian migration of last two decades and after is concerned with all the developments of Albania, including communist and post-communist time. All the development of Albania during the communist regime (1945-1990) is based on Marxist theory of transformation from capitalist to communist society. Marx writes

... between capitalist and communist society lies the period of the revolutionary transformation of the one into the other. Corresponding to this is also a political transition period in which the state can be nothing but the revolutionary dictatorship of the proletariat.

Scheme I: Communist transition, according to Marx

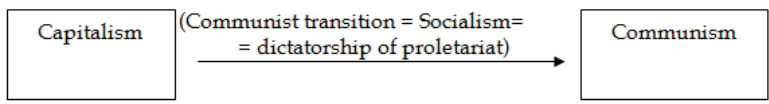

Marx (see, 1975: 226), says that the dictatorship of the proletariat is a necessary phase to move to the disappearance of class distinctions generally, to the disappearance of all the relationships in production upon which are based these class distinctions, the disappearance of all social relations that correspond to these relations in production, the overthrow of all ideas emanating from these social relations. So we have:

Scheme II: The features of Communist Transition (Karl Marks)

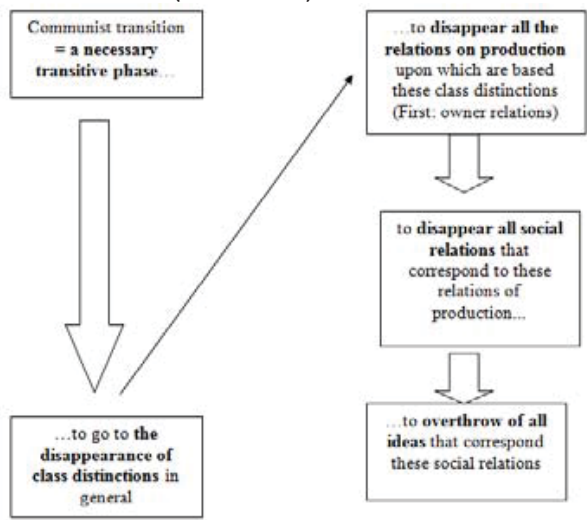


So the democratic transition interrupted another transition: the communist one. And, rreferring to Marx's scheme, and judging the depth of the transformations applied in Albania - compared with other countries of Eastern Europe - and the transformations performed comparably to other types of social transitions, we can say that:

First, of all types of transitions, the post communist transition is the most representative one. This is regarded to the quantity and depth of the transformations performed.

Second, the starting point of post-communist transitions was different in different countries. This depending on three factors: the level of development (1) the degree of application of Marx's formula - cited above, (2) and different levels of previous reforms (3).

Third, it is confirmed that only ten years after the fall of the Berlin Wall, the characterization of East European Countries as "post-communist," clearly lost every sense (Rupnik, 2002: 129-137). The common denominator of Hungary, Albania, the Czech Republic, Belarus or Kazakhstan shows almost nothing.

Forth, of all former communist countries, Albania represents a special case, first of all, because in no other country Marx's formula (quoted above) is implemented so faithfully, or blindly, than in Albania. All other countries have corrected the system, at least after "1960s. Albania, on the contrary, following the strategy "neither East nor West" went paradoxically in the road of the greater 'communistization': Albania of 1989 was a more communist country than in 1945 or in 1960. First, Albania was and remained the country with the highest level of the concentration of means of production in state hands. In Albania, as nowhere else, the state became the only owner and the only employer. The Albanian people were, as nowhere else, alienated to the state. But the state has lost these functions, immediately, in a very short time, let's say, in one year. Albanian citizen, totally alienated from the state, felt suddenly abandoned. The main question was just the survival, at any cost. The migration was just the "life-boat" (the boat of Noès")

Fifth, Albanian communism remains up to the end a "heavy communism", quite different from the "light communism" of other countries, such as the so-called the "communism of gulash" in Hungary, after the revolution of 1956. This means that Albania had some additional objective difficulties for a successful transition, against most other former communist countries. This is not only a metaphor. Albania based its economic development in the heavy industry, as well as in large cooperatives and agriculture farms. Almost all inhabitants of the city of Elbasan, for example, earned their own living from the the Metallurgical Combine, at that time with more than 14 thousand workers, so too much for a small country, such as Albania. In these conditions the process of transformations towards the market economy was and is still very difficult.

Sixth, in addition to this "plus objective difficulties" Albania had some "subjective additional difficulties", for a successful transition versus the majority of East European Countries. That's because, using with the words of the famous Zbigniew Brzezinski (1993) the behavior or engaging of the Albanian leaders towards a pluralist democracy has been and still is problematic.

The above arguments lead us to the generalization: if the post-communist transition is more representative; the Albanian post-communist transition is the most representative one. So, the Albanian transition is a kind of laboratory for the study of transitional processes, received generally.

Seventh, the migration of Albanians in such a great quantity was possible thanks to some other geographical and social factors. Albania is a European country, near to Greece and Italy. So it was possible to pass the border... Another social factor is concerned with the traditional connections of Albanians of Albania with the Albanians of Diaspora. Except the well known Jewish's experience, the Albanians represent the next case of spreading all over the world. The number of Albanians living abroad is valuated to be 3-4 times more than the Albanians of Albania itself. Now almost every Albanian, migrant or not is in a dilemma: to live in Albania or in another country. That's motivated not only from the financial capital (economic perspective), but also from the social capital (sociologic perspective) as well.

\section{Some Critical Themes of Migration and Some Conclusions Referring the Albanian Migratory Experience}

The attention of the scholars is concentrated first of all in the study of the impact of immigration on recipient countries, so in the countries of destination. From the late $19^{\text {th }}$ century to the mid $20^{\text {th }}$ century, the international migration was an important engine for economic growth in such destination countries as the United States, Canada, Argentina, Australia, Brazil, and New Zealand - the so-called New World countries. Most of the immigrants came from Europe (Ireland, Italy, Spain, Poland, and Scandinavia, and from Asian nations. In the early $21^{\text {st }}$ century, the geographical landscape of origin and destination countries for international migration has changed fundamentally. Many European and such Asian countries (such above mentioned) have turned from being, historically, net emigration countries to net recipient countries.

Albania is still a net migration country. But less attention is focused on studing the impact of migration on the 
countries of origin, such as the Albania. Almost all the studies are focused on economic impact, referring to remittances.

But, there are some Critical Themes to highlight the international migration, regarding Albanian experience:

First one is concerned with the size of migrants: from one third (Albanians living abroad) to half (Albanian that have experienced migration, during the same period of time). Is this connected with any "natural" feature of Albanians? The authors have written, anyhow, about "Albanians - as great recessives". The concept "recessives" is used to characterize Albanians as people almost genetically tended to go abroad, to move from their homeland. This approach, or conclusion, is not correct.

The Albanian Migration is an old and new phenomenon. But, during the history, there have been some waves of migration of the Albanians. The first one happened during the "40s of $14^{\text {th }}$ century, under a very severe occupation of the emperor Stephan Dusan (Stefan Dushani). Many Albanians were forced to migrate, first of all in Greece. Their successors (arvanitas of Greece) have preserved the Albanian language until today (Frasheri, 2008: 79). The second wave of Albanian exodus was during the $15^{\text {th }}$ century, at the end of Albanian resistance against Ottoman Empire under Skanderbeg. Again their successors (arberesh of Italy, and not only) have preserved the Albanian language until today and many Albanian traditions (Tirta, 1999: 1998). The third wave of Albanian migration was that of first half of $20^{\text {th }}$ century, around the First World War.

But in every case, the migration of Albanians has been a forced migration. Later, in the second half of $20^{\text {th }}$ century (up to 1990) Albania was totally (self) isolated by the rest of the world. Crossing the border was considered "treachery against the fatherland", and so the most serious crime. During the history the myth of homeland through Albanians has been always very strong (In a large volume of Maxims of the Albanian people, with about 14 thousand maxims, published by the Albanian Academy of Science in 1983, the first ones are: "my field, my tomb", "the most difficult obstacle to pass in the life of a man is the doorstep of the house/the threshold of the house" and so on).

From this 'picture' we can draw two conclusions: First, the history of Albania can not help us to explain the Albanian exodus of last twenty years. Second, the Albanian migrants have conserved the main features of national identity. And we can explain the Albanian exodus of 1991 and after only based on the specific developments of this country concluding that what happened in Albania, under the similar conditions, may happen in every country of the world.

The second Critical Theme of migration, regarding Albanian experience, is concerned with migrants, as contributors to the Albanian economy. Albanian experience shows the positive and negative aspects of migration on originated countries and, regarding remittances, their "potential benefits" and "potential costs". There are two opposing views on the issue of remittances' impacts on immigrant sending countries. One considers that remittances do not promote growth but on the contrary, they create dependency of sending countries on migration and decrease the likelihood of an improved economy. The next one considers the potential of remittance inflows to support growth and development. The table presents the views of the economic benefits and costs of remittances to a receiving country.

Table: Potential benefits and costs of remittances for receiving countries

\begin{tabular}{|l|l|}
\hline Potential benefits & Potential costs \\
\hline $\begin{array}{l}\text { Ease foreign exchange constraints and help } \\
\text { finance external deficits }\end{array}$ & $\begin{array}{l}\text { Ease pressure on governments to implement reforms and reduce external } \\
\text { imbalances (moral hazard) }\end{array}$ \\
\hline $\begin{array}{l}\text { Permit imports of capital goods and raw } \\
\text { materials for industrial development }\end{array}$ & $\begin{array}{l}\text { Are spent on consumer goods, which increases demand, increases inflation and } \\
\text { pushes up wage levels }\end{array}$ \\
\hline $\begin{array}{l}\text { Are potential source of savings and } \\
\text { investments for capital formation and } \\
\text { development }\end{array}$ & $\begin{array}{l}\text { Reduce savings of recipient families and thus negatively impact growth and } \\
\text { development (moral hazard) }\end{array}$ \\
\hline $\begin{array}{l}\text { Facilitate investment in children's education } \\
\text { and human capital formation }\end{array}$ & $\begin{array}{l}\text { Reduce labor effort of recipient families and thus negatively impact growth and } \\
\text { development (moral hazard) }\end{array}$ \\
\hline $\begin{array}{l}\text { Are net addition to families' income sources;; } \\
\text { raise the living standard of recipients }\end{array}$ & $\begin{array}{l}\text { Replace other sources of income, thereby increasing dependency, eroding good } \\
\text { work habits, and heightening potential negative effects of return immigration (moral } \\
\text { hazard) }\end{array}$ \\
\hline Reduce income inequality & Increase income inequality \\
\hline Reduce poverty & Promote the development of money laundering \\
\hline
\end{tabular}

Source: De Zwarg et al. 2005. Competing remittances, Tirana: IOM, pp. 37-38 
The impact of remittance flows on poverty reduction is not studied empirically. But according to the Living Standard Measuring Survey (LSMS) 2002, across all households, remittances from immigrants presented 13 per cent of the household income while for households that received remittances they presented 47 per cent of the household income. A key question concerning remittances is whether they affect the labor supply of household members that do not immigrate. Analyzing the impact of remittances on farming activity of rural households in Albania, they find that the provision of remittances significantly hindered farm efficiency, because of reduced labor effort. Clearly more qualitative and quantitative research has to be conducted. There is still a high dependence of Albania on remittances. A sudden decline in their size, due to a recession in the immigration countries for example could devastate the Albanian economy. And they finance mainly imports the "boomerang effect" (De Zwader et al, 2006).

Another Critical Theme of migration (the third one), regarding Albanian experience, is the impact of economic global crises on migratory issues. As observed in similar countries (Rua, 2010), the short-term impact of the economic global crisis in Albania covers al least three main areas: the first impact concerns the decrease for remittances; the second impact is the possibility that part of the migrant stock might return in Albania; the third area of impact is the decease in the flow of migration, mainly because of high unemployment rates in host countries (Gedeshi, 2010).

The forth Critical Theme of migration, regarding Albanian experience, is concerning with the conclusion that the international mobility of people is a controversial issue with attitudes ranging from openness and tolerance toward immigrants in good economic times, to reluctance and even xenophobia and resentment, particularly during times of economic slowdowns, unemployment, and financial insecurity such as the one we live in now after the financial crash of 2008-09.

The fifth Critical Themes of migration, regarding Albanian experience and not only, is concerning with the asymmetrical development of the world in the time of globalization. The nature of the current wave of globalization is such that international mobility of goods (commodities) and capital (money) across countries is much freer than the international mobility of people. Trade and capital-market regimes are more open than immigration regime. The asymmetric treatment of people's mobility in globalization opens the doors to various interpretations. In 1867 Karl Marx wrote, somewhat ironically, in the opening chapter of Capital about "commodity fetishism". His metaphor refers to social relationships that in capitalist societies apparently are transformed into objective relationships with commodities or money rather than relationships with people who produce those goods. Another asymmetries is between "knowledge workers" (or talented elites) and manual workers. This asymmetries can be called the "people's paradox of globalization" (Solimano, 2010).

Another Critical Theme is concerned with the dilemmas post by migration. One of them is regarded the illegal migration, with the conflict between Economic Logic and the Law. However, economic maturity is now coexisting with slow or stagnant population growth, low fertility rates, and an aging population. In some advanced economies, the population is shrinking. Thus, immigration provides much needed workers, professionals. Another one regards the conflict between economic logic and the immigrant's rights.

The seventh Critical Theme is concerned to the correlation between migration and development in the net migration countries, such as Albania. First this is connected with our concept of progress. The case of Albania shows that there is a great difference between changing and progress. Albanian migration has been the key factor of an "extroversion" economy, meaning that internal consumption greatly exceeds the capacity of national production.

The eighth Critical Theme is concerned with how we are measuring the progress. Albanian case shows the differences between the GDP growth and social progress. The present Albanian prime minister, for example, declared some days ago: "Germany and Albania are the more developed countries of Europe..." (Shqip, 19 August 2011). That's because the only point of reference for the development in Albania has been and still is the growth of GDP. In fact, the average growth of GDP in the last six years has been about 5 per cent. In this growth there is a great impact of Albanian migration.

But, the GDP of Albania is still very modest. With this cadency Albania can reach the average GDP of EU countries (supposing no growth of it) in about 50 years. What is more, the GDP growth is not an indicator of social progress. Economist Simon Kuznets was one of the architects of the US national account system. But, in his report presented in 1934, he categorically stated:

The welfare of a nation can scarcely be inferred from a measurement on national income (Cit, Marks, 2011).

More than twenty years later, in March 1958, speaking about the US measurement system, John Kennedy said:

Even if we act to erase material poverty, there is another greater task; it is to confront the poverty of satisfaction - 
purpose and dignity - that afflicts us all.

And after referring to a very high US GDP (at that time, Gross National Product) he continued:

\begin{abstract}
... but the Gross National Product counts air pollution and cigarette advertising, the ambulance to clear our highways of carnage. It counts special locks for our doors and the jails for the people who break them. It counts the destruction of the redwood and the loss of our natural wonder in chaotic sprawl... Yet the Gross National Production does not allow for the health of our children, the quality of their education or the joy of their play. It does not include the beauty of our poetry or the strength of our marriages, the intelligence of our public debate or the integrity of our public officials. It measures neither our wit nor our courage, neither our wisdom nor our learning, neither our compassion nor our devotion to our country. It measures everything in short, except that which makes life worthwhile.
\end{abstract}

Albanian experience as well as the experiences of other countries shows that Kennedy's words still ring true... The (re)valuation of the measuring system is a point of debate between economists and sociologists.

In Albania, during the communist rule (1944-1990), has not been any transparency about the material well-being of the people. Those data are considered "state secrets". Twenty years after the communist collapse, almost the only reference of the Albanian progress is still the growth of GDP (Telo, 1998). The official poverty line is not calculated in national level... From the growth of GDP to the social well-being - this must be the present debate through scholars, sociologists and economists, first.

The ninth Critical Theme, regarding Albanian migration, is concerned to the globalization of Albanian society, first thanks to migration. All the traditions are in discussion, even the national identity. The "transnationalization" of our societies requires further analysis. But there is a "state of inbetweenness" of Albanian migrants too. This is best expressed by a poem of Zafer Senocak called "Doppelmann" (cit. Abadan-Unat, 2003):

"I carry two words within me / but neither one hole / they're constantly bleeding / the border runs / right across my tongue..." (Nermin, 2003).

Anyhow, the challenges concerned with migration are quite different from the traditional ones. Whereas in the past most emigrants abandoned all symbolic ties of their place of origin and become citizens that took the local culture, spoke the local language, today more and more migrants retain significant, continuing ties with the countries of origin (AbadanUnat, 2003). With the support of electronic revolution, internet, and the other means of communication the migration has severed the ties between time and space, going to be part of a so-called "globalizing communitarianism beyond borders".

The intensification of Diaspora-home relations leads to the globalization of Albanian domestic politics may be as what has been called the "long distance nationalism" (what was a characteristic of Kosovar Abanians before their independence). While discussing the changing nature of relations between migrants and their new home country, we have a new discourse about migration and multiculturalism; "Hybridization" of Albania - focusing on increasing the number of Albanians leaving in transnational communities; Globalization of Albanian society, and Albanian issues, including politics... John Stuart Mill, in his time, has written about the impact of "placing human beings in contact persons dissimilar to themselves" considering as "one of the primary sources of progress".

The tenth and the last Critical Theme, regarding Albanian migration, is concerned to the changing of social relations and Albanian society, in general, thanks to migration, first. I would like to illustrate this changing referring to a sole case, taken as a case study.

It's the case of an Albanian, a PhD scholar, who has 'travelled" from a typical traditional Albanian family to a global family, perhaps in the real sense of this word. Here is what he confessed: "I am not an expert of international migration. But I have been an Albanian migrant for many years just in Greece and Italy, where are situated more than 80 per cent of Albanian migrants. I have shared my active life in two regimes: about 20 years in communist time (1971-1991) and 20 years (1991-2013) in the post-communist epoch. In the first phase I used to be a mechanical engineer more than everything else and, in the second phase, I used to be sociologist, more than everything else. So I can confess something from my experience, covered with a thin theoretical approach. It's not easy to imagine the traditional Albanian society and its dramatic change. I was born in a typical traditional region of Albania, with the magic name Dukagjin. It's hardly imagining a long line of men and women with tears in their eyes, when I first moved from. A nine years old boy from their kin was 'migrating'. In fact I was going to Shkodra (Scutari), the nearest city and the capital of the district. But this was considered migration. This picture remind up to 1991: every movement inside Albania was commanded by the state.

But I was an international migrant, being at the same time a sociologist, one of the first scholars of sociology in the 
history of my country (under the communist regime, so up to 1990, sociology was unplowed).

I spend several years in Greece and Italy, being part of the first wave of Albanian migration after the collapse of communist regime, of that biblical Albanian migration of 1991-1992. I experienced what a typical migrant used to experience. No more not less! I worked in more than 25 'professions', doing two or three jobs at the same time. Than I turned back in Albania, but...

20 years later; Koh Samui, Thailand 2011: The Library Hotel. My family is changed in a 'global' family. My sun got married with a 'cross-national' Korean-Canadian girl. The ceremony was organized in an island of Thailand. It was a non traditional marriage. The participants were from more than 20 countries. My sun was a global student, different schools, different countries, and different cultures. Now he is a global citizen, travelling a lot and working in different countries. My daughters the same: one is engaged and is going to be married with a 'cross-national' Persian-American boy, the next one the same..."

So, Albanian society is changing rapidly thanks - first - to migration. And Albania is sight that serves as cautionary example to other countries, as a kind of Social Laboratory for studying the migratory phenomenon in new Europe and global world.

\section{References}

Abadan-Unat, Nermin. (2003). "Moving towards European transnationalism: A Turkish View", Migration and labor in Europe, Istanbul: MURCIR \& NIWL.

Barjaba, Kosta. (2003). Shqiptarët, këta ikës të mëdhenj (Albanians, these great recessives). Tirana: Korbi.

De Soto, Hermine, Peter Gordon, llir Gedeshi \& Zamira Sinoimeri. (2003). Poverty in Albania. Tirana: The World Bank.

De Zwager, Nicolaas, llir Gëdeshi, Etleva Gjermeni \& Christos Nikas. (2005). Competing for Remittances. Tirana: IOM.

Germeni, E. (2000). Performance of Albanian imimmigrants in Greek labour market. Leuven: KU Leuven.

Gëdeshi, Ilir. (2010). Global Crisis and Migration; monitoring a key transmission channel to the Albanian economy, Tirana: UNDP \& IOM.

Giddens, Anthony. (2004). Sociology, 4th edition, London: Polity Press.

Goldin, Ian; Geoffery Cameron and Meera Balarajn. (2011). Exceptional people; how migration shaped our world and define our future, Oxford: Oxford University Press.

Huff, Darrell. (1985). How to lie with Statistics. London: Pelikan Books

INSTAT, Albanian Institute of Statistics. (2002). The population of Albania in 2001. Main result of the Population and Housing Census. Tirana: INSTAT.

King, Russal, Nicola Mai \& Stephanie Schwandner-Sievers. (2006). The New Albanian Immigration: Sussex Academic Press.

King, R, N. Mai \& M. Dalipaj. (2003). Exploding the immigration myth. Analysis and recommendations for the European Union, the UK and Albania, London: The Fabian Society and Oxfam.

King, Russell. (2011). "Albania as a Laboratory for the Study of Migration and Development", in Perpjekja, No. 26-27.

Marks, Nic. (2011). The Happiness Manifesto; How nations and people can nature well-being, London: Nef.

Marx, Karl \& Frederick Engels, and V.I. Lenin. (1984). on the Dictatorship of the Proletariat, Moscow, USSR: Progress Publishers.

Parkins, John. (2006). Confessions of an Economic Hit Man, New York: A Pluma Book.

Rupnik, Jacques. (2004). Balkans diary, Pristine: Kosovo Action for Civil Initiative.

Sokoli, Lekë \& llir Gëdeshi. (2006). Trafikimi, rasti i Shqipërisë (Human Trafficking, the Case of Albania): Tirana: Albanian Institute of Sociology.

Sokoli, Lekë. (2010). The equivoques of transition (Ekuivoket e tranzicionit), Gjeopolitika (Geopolitics), nr. 5, 2010, pp. 78-98. (2011). "Social differentiations and poverty: Albania in East European context", Studime sociale (Social studies), Vol. 4, №. 1, pp. 78-89.

Solimano, Andrés. (2010). International Migration in the Age of Crisis and Globalization; Historical and Recent Experiences, Cambridge: Cambridge University Press.

Tela, llia. 1998. Well-eing and the poverty line, Tirana: Albanian Demographs Association.

Tirta, Mark. (1999). Migration of Albanians (Albanian ethnography, no. 18), Tiranë: Shkenca.

Vullnetari, Julie. (2011). "From communist 'gulag' to Balkan 'ghetto': Albania and its migratory policies", in Perpjekja, No. 26-27.

Whitaker, K. S. (1996). "Explaining Cases of Principal burnout". Journal of Educational Administration 34, 1: 60-71.

White, G. (1981). Party and professionals: The political Role of Teachers in Contemporary China. Armonk, NY: M. E. Sharpe. 